\title{
KARIERNO IZOBRAŽEVANJE ZA LJUDI V POZNEJŠIH LETIH \\ Kvantitativna analiza rezultatov raziskave o kariernem izobraževanju
}

Mag. Marija Turnšek Mikačić

Glotta Nova,

Ljubljana

\section{POVZETEK}

Rezultati raziskave o kariernem izobraževanju na podlagi idejnega modela kariernega načrta kot gradnika osebne odličnosti odraslih so pokazali, da posamezniki, ki so izdelali osebni karierni načrt in se po njem ravnajo, spremenijo odnos do kariere in prevzamejo nadzor nad svojim življenjem. Ti posamezniki dosežejo visoko stopnjo samozaupanja in samozavesti ter imajo večjo percepcijo osebne odličnosti kot tisti, ki se niso izobraževali za kariero in niso izdelali kariernega načrta. Ugotovitve raziskave so praktično uporabne za reševanje socialnih problemov ljudi ter racionalizacijo stroškov javnih institucij, podjetij in zavodov za zaposlovanje. Zlasti pa so koristne za posameznike, saj se lahko na njihovi podlagi izognejo kariernemu prelomu, ki ga prinaša brezposelnost. Slednjega zamenja karierni prehod, ki ponuja različne karierne poti.

Ključne besede: karierno načrtovanje, raziskava kariernega izobraževanja, osebna odličnost, kvantitativna analiza, izobraževanje odraslih

\section{CAREER EDUCATION FOR OLDER PEOPLE A quantitative analysis of the results of career education, and confirmation of hypotheses - ABSTRACT}

The results of a study on career education, based on the career plan as a building block of personal excellence, have shown that the individuals with an individual career plan will change their attitude towards their career and take control of their lives. These individuals achieve a higher degree of self-confidence and attain awareness of a higher personal excellence than the individuals without career education or a career plan. The research results are applicable also to other areas, for instance in dealing with social problems, cost cutting in public enterprises and employment agencies etc. The findings are particularly useful for individuals to help them avoid a break in their careers, i.e. unemployment, replacing it with a career transition, which offers diverse career pathways.

Keywords: career planning, research of career education, personal excellence, quantitative analyses, education of adults

UDK: 374.7

\section{UVOD}

V članku so predstavljeni rezultati raziskave o kariernem izobraževanju ljudi v poznejših letih. Potem ko smo postavili paradigmatski model in razvili končno teorijo v okviru kvalitativne analize, smo oblikovali vprašalnik, pri čemer smo izhajali tudi iz lastnih izkušenj pri izobraževanju uporabnikov. Po končanem anketiranju smo opravili analizo notranje konsistentnosti vprašalnika, da bi izključili vse trditve, ki bi imele nizko vrednost interne konsistentnosti.

Članek povzema: raziskovalne hipoteze, opis empirične metode raziskovanja, potek kvantitativne analize, opis vzorca, odnos anketirancev do kariere, samopodobe in samozaupanja ter njihovega zaznavanje osebne odličnosti, bivariantno analizo, t-test za ne- 
odvisne spremenljivke, faktorsko analizo ter ključne ugotovitve kvantitativne analize. V zaključku povzemamo ugotovitve: kakšen je lahko vpliv raziskave na družbo, družbeno odgovornost in okolje, kakšen je lahko vpliv na menedžerje in organizacijo oziroma prakso, kakšen je izvirni prispevek raziskave $\mathrm{k}$ razvoju ustreznega znanstvenega področja, ter nakažemo omejitve raziskave in nadaljnje možne smeri raziskovanja.

\section{KAKO SMO RAZISKOVALI}

$\mathrm{Z}$ raziskavo smo preverili naslednje hipoteze: posamezniki, ki so izdelali osebni karierni načrt in se po njem ravnajo, spremenijo odnos do kariere in prevzamejo nadzor nad svojim življenjem, dosežejo visoko stopnjo samozaupanja in samozavesti ter imajo večjo percepcijo osebne odličnosti kot posamezniki, ki se niso izobraževali za kariero in niso izdelali kariernega načrta.

Opis empirične metode raziskovanja Opravili smo kvantitativno in kvalitativno analizo kariernega izobraževanja. V članku prikazujemo rezultate kvantitativne analize.

\section{Kvantitativna analiza kariernega izobraževanja - $\mathrm{Z}$ vprašalnikom smo zbrali podatke na namenskem vzorcu 320 udeležencev izobraževanja (nadalje: skupina A), pri katerem je šlo za izbiro posameznikov, ki izkazujejo lastnosti, relevantne za študijo (od njih smo lahko dobili koristne informacije}

za dosego cilja). Drug vzorec je obsegal 420 neudeležencev izobraževanja (nadalje: skupina B), kjer se enote vzorca v relevantnih lastnostih ne razlikujejo od enot populacije (delna populacija, ki je tipična, povprečna, predstavnica delovno aktivne populacije).

Oblikovanje vprašalnika - Vprašalnik smo oblikovali sami na podlagi paradigmatskega modela končne teorije pri kvalitativni raziskavi in lastnih izkušenj pri udeležencih seminarja kariernega izobraževanja (Turnšek Mikačić, 2010a). Po končanem anketiranju smo opravili analizo notranje konsistentnosti, da bi izključili vse trditve, ki bi imele nizko vrednost interne konsistentnosti.

Testiranje veljavnosti in zanesljivosti vprašalnika - Namen testiranja vprašalnika je ugotoviti, do katere mere dobljeni odgovori potrjujejo, da vprašalnik meri tisto, kar naj bi meril. Določili smo veljavnost vprašalnika (validity).

Prav tako smo preverili, do katere mere vprašalnik meri atribute na sistematičen in ponovljiv način, torej njegovo konsistentnost oziroma zanesljivost (reliability).

Interna konsistentnost ali homogenost (iter-item consistency) - Ugotovili smo konsistentnost med postavkami (odgovori), ki tvorijo posamezne faktorje, to se pravi, ali je odgovor na neko vprašanje v pričakovani povezavi z odgovori na vsa druga vprašanja, ki merijo isto spremenljivko oziroma isto stvar.

Slika 1a: Poslani in odgovorjeni vprašalniki v skupini $A$ in skupini $B$

\begin{tabular}{|l|l|l|l|}
\cline { 2 - 4 } \multicolumn{1}{c|}{} & Št. poslanih vprašalnikov & Št. odgovorienih vprašalnikov & Delež (v \%) \\
\hline Udeleženci & 320 & 272 & 0,85 \\
\hline Neudeleženci & 420 & 273 & 0,65 \\
\hline Skupai & 740 & 545 & 0,74 \\
\hline
\end{tabular}




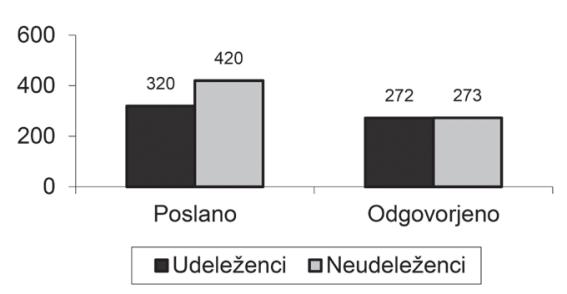

Slika 1b: Odstotek odgovorjenih vprašalnikov pri skupini $A$ in skupini $B$

\begin{tabular}{|l|l|}
\cline { 2 - 2 } \multicolumn{1}{c|}{} & Odstotek \\
\hline Udeleženci & 0,85 \\
\hline Neudeleženci & 0,65 \\
\hline Skupai & 0,74 \\
\hline
\end{tabular}

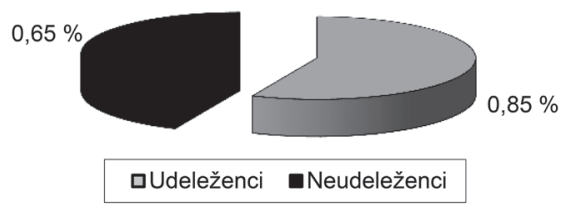

Kot merilo interne konsistentnosti smo uporabili Cronbachov koeficient $\alpha$.

Izvedli smo teste interne konsistentnosti znotraj posameznih faktorjev: Moj odnos do kariere (K), Samopodoba (L) in Percepcija osebne odličnosti (M).

Interna konsistentnost je potrjena, če je Cronbachov koeficient $\alpha$ večji od 0,5 .
Test interne konsistentnosti - Prikazujemo le rezultate za spremenljivko Moj odnos do kariere, za preostali dve spremenljivki so podatki podobni. Cronbachov koeficient $\alpha$ je bil določen za vsako skupino posebej, tako za skupino A kot skupino B. Analiza je pokazala, da je pri obeh skupinah merski instrument zanesljiv. Atribute meri na sistematičen in ponovljiv način, vrednost Cronbachovega koeficienta $\alpha$ je pri skupini A višja od 0,8 , pri skupini B pa od 0,9.

Test veljavnosti vprašalnika - Uporabili smo Spearman-Brownov koeficient in vprašalnik razdelili na dve polovici tako za skupino $\mathrm{A}$ kot tudi za skupino B.

Rezultate prikazujemo le za spremenljivko Moj odnos do kariere, za preostali dve spremenljivki so podatki podobni (Turnšek Mikačić, 2013).

Vprašalnik smo razdelili na polovici po načelu liha/soda vprašanja, nato smo izračunali Spearman-Brownov koeficient za vsako spremenljivko za obe skupini. Analiza je pokazala, da dobljeni rezultati ustrezajo namenu oziroma da vprašalnik meri tisto, kar naj bi meril.

Vsi Spearman-Brownovi koeficienti so, podobno kot Cronbachovi koeficienti $\alpha$, veliki (večji od 0,80 ), so pa nekoliko manjši pri skupini A v primerjavi s skupino B. Ugotovimo lahko, da vprašalnik veljavno meri stališča vprašanih.

Tabela 1: Povprečne vrednosti in standardni odkloni vzorca skupine $A$ in skupine $B$

\begin{tabular}{|l|l|l|l|l|l|l|}
\hline Kriterij & & Skupina A & & & Skupina B & \\
\hline & Vsi odgovori & Povprečje & $\begin{array}{l}\text { Standardni } \\
\text { odklon }\end{array}$ & Vsi odgovori & Povprečje & $\begin{array}{l}\text { Standardni } \\
\text { odklon }\end{array}$ \\
\hline Spol & 272 & 1,65 & 0,478 & 273 & 1,67 & 0,480 \\
\hline Starost & 272 & 4,14 & 1.346 & 273 & 4,33 & 1.483 \\
\hline Izobrazba & 272 & 4,47 & 1.239 & 273 & 4,47 & 1.191 \\
\hline
\end{tabular}




\begin{tabular}{|l|l|l|l|l|l|l|}
\hline Kriterij & & Skupina A & & & Skupina B & \\
\hline & Vsi odgovori & Povprečje & $\begin{array}{l}\text { Standardni } \\
\text { odklon }\end{array}$ & Vsi odgovori & Povprečje & $\begin{array}{l}\text { Standardni } \\
\text { odklon }\end{array}$ \\
\hline Zaposlitveno stanje & 271 & 4,35 & 1.398 & 273 & 4,69 & 1.527 \\
\hline Število let zaposlitve & 272 & 3,68 & 1.490 & 273 & 3,87 & 1.501 \\
\hline Vključenost v izobraževanje & 272 & 1,74 & 0,756 & 273 & 1,76 & 0,605 \\
\hline Računalniški tečai & 272 & 0,30 & 0,460 & 273 & 0,32 & 0,468 \\
\hline Jezikovni tečaj & 272 & 0,29 & 0,456 & 273 & 0,33 & 0,472 \\
\hline Seminar učinkovite komunikacije & 272 & 0,56 & 0,497 & 273 & 0,24 & 0,429 \\
\hline Osebni karierni načrt & 272 & 0,80 & 0,402 & 273 & 0,00 & 0,000 \\
\hline Izobraževanje iz menedžmenta & 272 & 0,30 & 0,458 & 273 & 0,20 & 0,402 \\
\hline Izobraževanje za poslovni načrt & 272 & 0,39 & 0,489 & 273 & 0,00 & 0,000 \\
\hline Izobrazevanje za načrtovanja kariere & 272 & 1,53 & 0,850 & 273 & 1,81 & 0,963 \\
\hline Europass & 272 & 1,29 & 0,549 & 273 & 1,61 & 0,597 \\
\hline Delavnice osebnega kariernega načrta & 272 & 1,14 & 0,378 & 273 & 1,56 & 0,512 \\
\hline Skupno število spremenliivke & 271 & & & 273 & & \\
\hline
\end{tabular}

Opis vzorca - Prikazujemo vzorca skupine A in skupine B, pri čemer smo imeli pri tistih, ki so odgovorili na anketo, naslednjo strukturo: v skupini A je bilo 65,1 odstotka žensk in 34,9 odstotka moških, standardni odklon je 0,478 ; v skupini B je bilo 65,9 odstotka žensk in 33,7 odstotka moških, standardni odklon je 0,480 .

Na podlagi analize obeh vzorcev lahko ugotovimo, da se skupini dobro ujemata po spolu, starosti, izobrazbi, zaposlitvenem položaju in številu let zaposlitve. Standardni odklon kaže nekoliko večjo porazdelitev med skupino B.

V primerjavi s povprečjem populacije zaposlenih v Sloveniji sta bili anketirani skupini starejši in nekoliko višje izobraženi.

Iz Tabele 1 povzemamo:

Slika 2: Spol skupine A

\begin{tabular}{|l|l|l|}
\hline Spol & F & Odstotek \\
\hline Moški & 95 & 34,9 \\
\hline Ženske & 177 & 65,1 \\
\hline Skupai & 272 & 100,0 \\
\hline
\end{tabular}

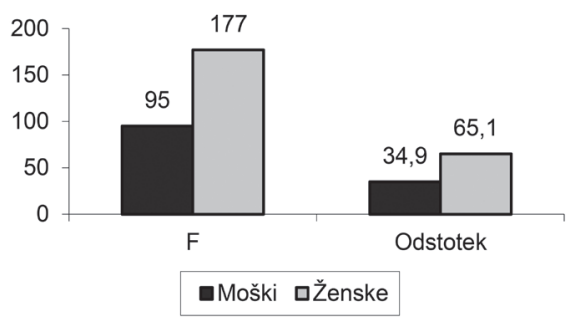

Slika 3: Spol skupine B

\begin{tabular}{|l|l|l|}
\hline Spol & F & Odstotek \\
\hline Moški & 92 & 33,7 \\
\hline Ženske & 180 & 65,1 \\
\hline Skupai & 272 & 99,6 \\
\hline
\end{tabular}

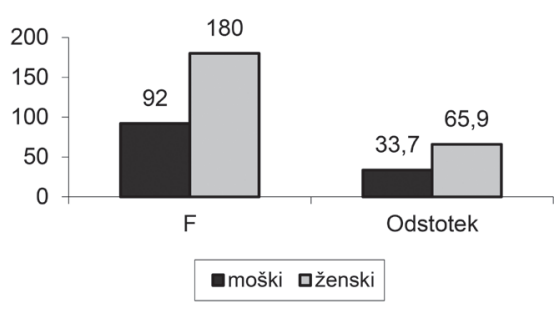


Slika 4: Starost skupine A

\begin{tabular}{|l|l|l|}
\hline Starost & F & Odstotek \\
\hline $18-24$ let & 3 & 1,1 \\
\hline $25-34$ let & 32 & 11,8 \\
\hline $35-44$ let & 52 & 19,1 \\
\hline $45-54$ let & 78 & 28,7 \\
\hline $55-64$ let & 58 & 21,3 \\
\hline 65 let ali več & 42 & 15,4 \\
\hline Ne želim odgovoriti & 7 & 2,6 \\
\hline Skupaj & 272 & 100 \\
\hline
\end{tabular}

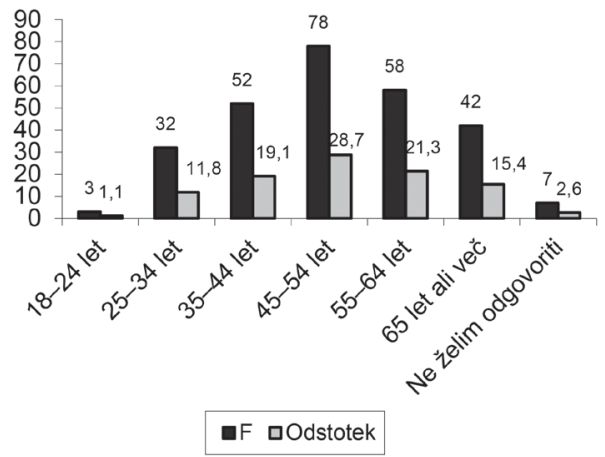

Slika 5: Starost skupine B

\begin{tabular}{|l|l|l|}
\hline Starost & F & Odstotek \\
\hline $18-24$ let & 5 & 1,8 \\
\hline $25-34$ let & 21 & 7,7 \\
\hline $35-44$ let & 64 & 23,4 \\
\hline $45-54$ let & 59 & 21,6 \\
\hline $55-64$ let & 61 & 22,3 \\
\hline 65 let ali več & 40 & 14,7 \\
\hline Ne želim odgovoriti & 22 & 8,1 \\
\hline Ni odgovora & 1 & 0,4 \\
\hline Skupai & 273 & 100 \\
\hline
\end{tabular}

Vir: Tabela 1

Povprečna starost v obeh skupinah je bila med 45 in 54 let, s tem da je bila skupina A za kako leto mlajša. Standardni odklon je bil pri skupini A 1,346, pri skupini B pa 1,483.

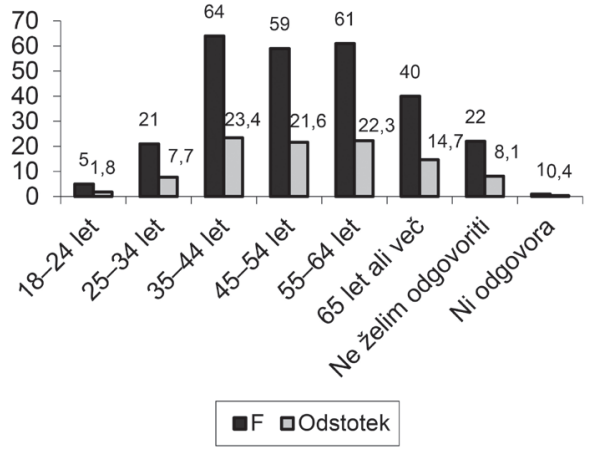

Povprečna starost zaposlene populacije je bila v Sloveniji junija 201241 let (Statistični urad Republike Slovenije).

\section{ODNOS DO KARIERE,} SAMOPODOBE IN SAMOZAUPANJA TER ZAZNAVANJE OSEBNE ODLIČNOSTI

V anketi smo postavili vprašanja, ki se nanašajo na vedenjske vzorce po končanem izobraževanju (Turnšek Mikačić, 2013):

- na doživljanje spremenjenega odnosa do kariere,

- na doživljanje spremenjene samopodobe in samozaupanja in

- na zaznavo osebne odličnosti.

Posamezne dimenzije vedenjskih vzorcev so anketiranci izražali s pomočjo petstopenjske Likertove lestvice, pri kateri so imeli na voljo naslednje možnosti:

Tabela 3: Povprečje in standardni odklon - spremenljivka Moj odnos do kariere pri skupini $A$ in skupini $B$

\begin{tabular}{|l|l|l|l|l|}
\hline Sploh ne & V manjši meri & $\begin{array}{l}\text { Deloma da, } \\
\text { deloma ne }\end{array}$ & $\begin{array}{l}\text { To velja za } \\
\text { mene }\end{array}$ & $\begin{array}{l}\text { To popolno- } \\
\text { ma velja za } \\
\text { mene }\end{array}$ \\
\hline 1 & 2 & 3 & 4 & 5 \\
\hline
\end{tabular}

Vir: Likert, R. (1932) 
Tabela 3: Povprečje in standardni odklon - spremenliivka Moj odnos do kariere pri skupini A in skupini B

\begin{tabular}{|l|l|l|l|l|l|l|}
\cline { 2 - 7 } \multicolumn{1}{c|}{} & & Skupina A & & Skupina B & & \\
\cline { 2 - 7 } \multicolumn{1}{l|}{} & Vsi odgovori & Povprečje & $\begin{array}{l}\text { Standardni } \\
\text { odklon }\end{array}$ & Vsi odgovori & Povprečje & $\begin{array}{l}\text { Standardni } \\
\text { odklon }\end{array}$ \\
\hline K0 & 272 & 4,27 & 0,778 & 273 & 2,91 & 1,219 \\
\hline K1 & 272 & 3,84 & 0,824 & 273 & 2,42 & 1,034 \\
\hline K2 & 272 & 3,96 & 0,743 & 273 & 2,44 & 1,045 \\
\hline K3 & 272 & 4,06 & 0,734 & 273 & 2,38 & 1,026 \\
\hline K4 & 272 & 3,79 & 0,831 & 273 & 2,3 & 1,011 \\
\hline K5 & 272 & 3,67 & 0,969 & 273 & 2,23 & 1,007 \\
\hline K6 & 272 & 4,12 & 0,73 & 273 & 2,45 & 1,08 \\
\hline K7 & 272 & 4,2 & 0,727 & 273 & 2,84 & 1,102 \\
\hline K8 & 272 & 3,6 & 0,944 & 273 & 2,24 & 1 \\
\hline K9 & 272 & 4,16 & 0,7 & 273 & 2,6 & 0,958 \\
\hline K10 & 272 & 4,09 & 0,784 & 273 & 2,7 & 1,011 \\
\hline K11 & 272 & 4,37 & 0,701 & 273 & 2,79 & 1,067 \\
\hline K12 & 272 & 4,32 & 0,674 & 273 & 2,79 & 1,05 \\
\hline
\end{tabular}

Bivariatna analiza - Ker so spremenljivke številske, smo v korelacijski matriki testirali linearno povezanost posameznih parov spremenljivk. Spearmanov koeficient korelacije je za vsak par pokazal, ali med njima obstaja povezanost. Ta koeficinet je definiran na intervalu od -1 do 1 . Vrednost 0 pomeni, da ni povezanosti, vrednost -1 pomeni največjo možno obratnosorazmerno povezanost in 1 največjo možno premosorazmerno povezanost. Vrednosti od 0 do 0,3 kažejo šibko povezanost, vrednosti nad 0,3 do 0,6 srednje močno povezanost in nad 0,6 do 1 zelo močno povezanost.

Pri skupini A lahko z manj kot 0,1-odstotnim tveganjem trdimo, da obstaja srednje močna povezanost med odnosom do kariere in samopodobo, kar kaže Spearmanov koeficient korelacije 0,465. Boljša kot je samopodoba, boljši je odnos do kariere in obratno.
Slika 6: Povprečne vrednosti indikatorja spremenljivke $\mathrm{K}$ »Moj odnos do kariere»

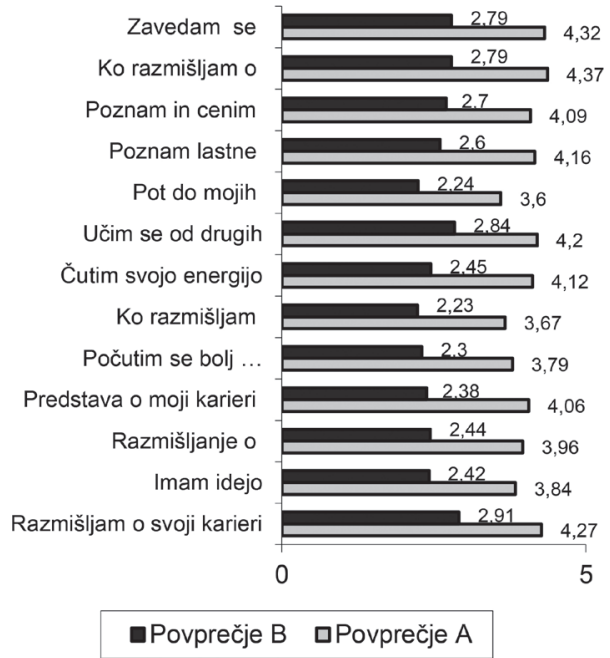


Tabela 4: Korelacijska tabela za skupino A

\begin{tabular}{|c|c|c|c|c|c|}
\hline & & & K & L & $M$ \\
\hline \multirow{9}{*}{$\begin{array}{l}\text { Spearmanov } \\
\text { r koeficient } \\
\text { korelacije ranga }\end{array}$} & \multirow[t]{3}{*}{ K } & $\begin{array}{l}\text { Korelacijski } \\
\text { koeficient }\end{array}$ & 1,000 & 0,465 & 0,340 \\
\hline & & $\begin{array}{l}\text { Stopnja } \\
\text { značilnosti }\end{array}$ & . & 0,000 & 0,000 \\
\hline & & $\mathrm{N}$ & 272 & 272 & 272 \\
\hline & \multirow[t]{3}{*}{ L } & $\begin{array}{l}\text { Korelacijski } \\
\text { koeficient }\end{array}$ & 0,465 & 1.000 & 0,652 \\
\hline & & $\begin{array}{l}\text { Stopnja } \\
\text { značilnosti }\end{array}$ & 0,000 & - & 0,000 \\
\hline & & $\mathrm{N}$ & 272 & 272 & 272 \\
\hline & \multirow[t]{3}{*}{$M$} & $\begin{array}{l}\text { Korelacijski } \\
\text { koeficient }\end{array}$ & 0,340 & 0,652 & 1.000 \\
\hline & & $\begin{array}{l}\text { Stopnja } \\
\text { značilnosti }\end{array}$ & 0,000 & 0,000 & - \\
\hline & & $N$ & 272 & 272 & 272 \\
\hline
\end{tabular}

Z manj kot 0,1-odstotnim tveganjem tudi lahko trdimo, da pri skupini A obstaja srednje močna povezanost med odnosom do kariere in percepcijo osebne odličnosti, kar kaže Spearmanov koeficient 0,340. Boljši kot je odnos do kariere, boljša je percepcija osebne odličnosti in obratno. Z manj kot 0,1-odstotnim tveganjem prav tako lahko trdimo, da v skupini A obstaja zelo močna povezanost med samopodobo in percepcijo osebne odličnosti, kar kaže Spearmanov koeficient 0,652 . Boljša kot je samopodoba, boljša je percepcija osebne odličnosti in obratno.

T-test za neodvisne spremenljivke - Pri preverjanju razlik med skupinama smo uporabili t-test za neodvisne vzorce, ki je namenjen medsebojni primerjavi dveh neodvisnih skupin. S t-testom smo preverjali, ali se aritmetični sredini naših skupin med seboj statistično pomembno razlikujeta. Pri vseh testih smo upoštevali petodstotno stopnjo tveganja. Ugotavljali smo vpliv
Tabela 5: T-test

\begin{tabular}{|l|l|l|l|l|l|}
\cline { 2 - 6 } \multicolumn{1}{|c|}{} & $\begin{array}{l}\text { Karierni } \\
\text { poslovni } \\
\text { načrt }\end{array}$ & $\mathrm{N}$ & $\begin{array}{l}\text { Srednia } \\
\text { vrednost }\end{array}$ & $\begin{array}{l}\text { Standardni } \\
\text { odklon }\end{array}$ & $\begin{array}{l}\text { Standardna } \\
\text { napaka } \\
\text { srednje } \\
\text { vrednosti }\end{array}$ \\
\hline \multirow{2}{*}{$\mathrm{K}$} & $\begin{array}{l}\text { brez } \\
\text { OKN+PN }\end{array}$ & 273 & 25.449 & 0,72953 & 0,04415 \\
\hline $\begin{array}{l}\text { OKN+PN } \\
\text { skupai }\end{array}$ & 272 & 40.348 & 0,46595 & 0,02825 \\
\hline $\mathrm{L}$ & $\begin{array}{l}\text { brez } \\
\text { OKN+PN }\end{array}$ & 273 & 28.425 & 0,63667 & 0,03853 \\
\hline $\begin{array}{l}\text { OKN+PN } \\
\text { skupai }\end{array}$ & 272 & 41.000 & 0,43583 & 0,02643 \\
\hline $\mathrm{M}$ & $\begin{array}{l}\text { brez } \\
\text { OKN+PN }\end{array}$ & 273 & 28.956 & 0,53982 & 0,03267 \\
\hline & $\begin{array}{l}\text { OKN+PN } \\
\text { skupai }\end{array}$ & 272 & 41.715 & 0,41185 & 0,02497 \\
\hline
\end{tabular}

osebnega kariernega načrta in poslovnega načrta skupaj na odnos do kariere (K), na samopodobo (L) in percepcijo osebne odličnosti (M).

\section{AS $2 / 20$}


Tabela 6: T-test za neodvisne vzorce

\begin{tabular}{|c|c|c|c|c|c|c|c|c|c|c|}
\hline & \multicolumn{2}{|c|}{$\begin{array}{l}\text { Levenov test za prever- } \\
\text { janje enakosti varianc }\end{array}$} & \multicolumn{7}{|c|}{ t-test za enakost srednje vrednosti } \\
\hline & & \multirow[b]{2}{*}{$\mathrm{F}$} & \multirow[b]{2}{*}{$\begin{array}{l}\text { Stopnja } \\
\text { značilnosti }\end{array}$} & \multirow[b]{2}{*}{$\mathrm{T}$} & \multirow[b]{2}{*}{$\begin{array}{l}\text { Stopnja } \\
\text { prostosti }\end{array}$} & \multirow[b]{2}{*}{$\begin{array}{l}\text { Stopnja } \\
\text { značilnosti }\end{array}$} & \multirow[b]{2}{*}{$\begin{array}{l}\text { Razlika } \\
\text { povprečii }\end{array}$} & \multirow[b]{2}{*}{$\begin{array}{l}\text { Stand. } \\
\text { napaka } \\
\text { ocene } \\
\text { razlike }\end{array}$} & \multicolumn{2}{|c|}{$\begin{array}{l}95 \% \text { stopnja zaupanja } \\
\text { za aritmetično sredino }\end{array}$} \\
\hline & & & & & & & & & $\begin{array}{l}\text { Spodnja } \\
\text { meja }\end{array}$ & $\begin{array}{l}\text { ZGORNJA } \\
\text { MEJA }\end{array}$ \\
\hline \multirow[t]{2}{*}{ K } & $\begin{array}{l}\text { Predvide- } \\
\text { na enakost } \\
\text { varianc }\end{array}$ & 43.132 & 0,000 & -28.400 & 543 & 0,000 & -148.984 & 0,05246 & -159.289 & -138.679 \\
\hline & $\begin{array}{l}\text { Enakost } \\
\text { varianc ni } \\
\text { predvide- } \\
\text { na }\end{array}$ & & & -28.422 & 462.509 & 0,000 & -148.984 & 0,05242 & -159.285 & -138.683 \\
\hline \multirow[t]{2}{*}{$\mathrm{L}$} & $\begin{array}{l}\text { Predvide- } \\
\text { na enakost } \\
\text { varianc }\end{array}$ & 21.316 & 0,000 & -26.896 & 543 & 0,000 & -125.751 & 0,04675 & -134.935 & -116.567 \\
\hline & $\begin{array}{l}\text { Enakost } \\
\text { varianc ni } \\
\text { predvide- } \\
\text { na }\end{array}$ & & & -26.914 & 481.191 & 0,000 & -125.751 & 0,04672 & -134.932 & -116.570 \\
\hline \multirow[t]{2}{*}{ M } & $\begin{array}{l}\text { Predvide- } \\
\text { na enakost } \\
\text { varianc }\end{array}$ & 11.300 & 0,001 & -31.011 & 543 & 0,000 & -127.585 & 0,04114 & -135.667 & -119.504 \\
\hline & $\begin{array}{l}\text { Enakost } \\
\text { varianc ni } \\
\text { predvide- } \\
\text { na }\end{array}$ & & & -31.026 & 508.464 & 0,000 & -127.585 & 0,04112 & -135.664 & -119.506 \\
\hline
\end{tabular}

Skupina A (OKN + PN skupaj) ima v povprečju višje vrednosti spremenljivk $K, L$ in $M$.

Razlike so statistično značilne, saj je interval zaupanja za razliko med obema neodvisnima spremenljivkama pravilen v 95 odstotkih primerov $(\sigma<0,005)$. Standardni odklon je lahko računan kot $\sigma$ (sigma), in sicer kot odklon celotne populacije ali njene naključne spremenljivke.Tako lahko sklepamo, da udeležba kariere, samopodobo in percepcijo osebne odličnosti.

Faktorska analiza - Faktorska analiza je ena izmed metod za redukcijo podatkov. Pri faktorski analizi gre za študij povezav med spremenljivkami v smislu, da poskušamo najti novo množico spremenljivk, ki predstavljajo to, kar je opazovanim spremenljivkam skupnega. Z drugimi besedami: faktorska analiza poskuša poenostaviti kompleksnost povezav med množico opazovanih spremenljivk $\mathrm{z}$ razkritjem 
Tabela 7: Razlaga skupne variance

\begin{tabular}{|c|c|c|c|c|c|c|c|c|c|}
\hline \multirow[t]{2}{*}{ Faktor } & \multicolumn{3}{|c|}{ Začetne lastne vrednosti } & \multicolumn{3}{|c|}{ Izločitev vsote kvadrata zasičenosti } & \multicolumn{3}{|c|}{ Rotacija vsote kvadrata zasičenosti } \\
\hline & Skupai & $\%$ variance & $\begin{array}{l}\text { Kumulativni } \\
\% \text { variance }\end{array}$ & Skupai & $\%$ variance & $\begin{array}{l}\text { Kumulativni } \\
\% \text { variance }\end{array}$ & Skupaj & $\%$ variance & $\begin{array}{l}\text { Kumulativni } \\
\% \text { variance }\end{array}$ \\
\hline 1 & 6.759 & 30.723 & 30.723 & 6.759 & 30.723 & 30.723 & 2.842 & 12.918 & 12.918 \\
\hline 2 & 1.480 & 6.726 & 37.449 & 1.480 & 6.726 & 37.449 & 2.756 & 12.525 & 25.443 \\
\hline 3 & 1.448 & 6.584 & 44.033 & 1.448 & 6.584 & 44.033 & 2.404 & 10.927 & 36.370 \\
\hline 4 & 1.341 & 6.095 & 50.128 & 1.341 & 6.095 & 50.128 & 1.877 & 8.533 & 44.903 \\
\hline 5 & 1.222 & 5.554 & 55.682 & 1.222 & 5.554 & 55.682 & 1.758 & 7.990 & 52.893 \\
\hline 6 & 1.091 & 4.958 & 60.640 & 1.091 & 4.958 & 60.640 & 1.704 & 7.747 & 60.640 \\
\hline 7 & 0,951 & 4.323 & 64.963 & & & & & & \\
\hline 8 & 0,814 & 3.698 & 68.661 & & & & & & \\
\hline 9 & 0,792 & 3.602 & 72.263 & & & & & & \\
\hline 10 & 0,711 & 3.234 & 75.497 & & & & & & \\
\hline 11 & 0,652 & 2.965 & 78.462 & & & & & & \\
\hline 12 & 0,643 & 2.921 & 81.383 & & & & & & \\
\hline 13 & 0,615 & 2.795 & 84.178 & & & & & & \\
\hline 14 & 0,572 & 2.600 & 86.779 & & & & & & \\
\hline 15 & 0,536 & 2.438 & 89.217 & & & & & & \\
\hline 16 & 0,493 & 2.241 & 91.458 & & & & & & \\
\hline 17 & 0,436 & 1.984 & 93.441 & & & & & & \\
\hline 18 & 0,366 & 1.662 & 95.103 & & & & & & \\
\hline 19 & 0,340 & 1.546 & 96.649 & & & & & & \\
\hline 20 & 0,316 & 1.439 & 98.088 & & & & & & \\
\hline 21 & 0,233 & 1.060 & 99.148 & & & & & & \\
\hline 22 & 0,187 & 0,852 & 100.000 & & & & & & \\
\hline
\end{tabular}

Metoda ekstrakcije: Faktoring glavne osi

skupnih razsežnosti ali faktorjev, ki omogočajo vpogled v osnovno strukturo podatkov. S faktorsko analizo ugotovimo, ali so zveze med opazovanimi spremenljivkami (ali indikatorji) pojasnljive z manjšim številom posredno opazovanih spremenljivk ali faktorjev.

Prvi faktor predstavlja 30,72 odstotka celotne variabilnosti merjenih spremenljivk (Tabela 7). Ker imajo vsi indikatorji pri prvem faktorju največje uteži, smo novo spremenljivko Percepcija osebne odličnosti tudi tu izračunali na podlagi povprečnih vrednosti 22 indikatorjev, kjer imajo povprečne vrednosti vseh 22 indikatorjev velike uteži na prvem faktorju (Tabela 8).

Sestavljena spremenljivka Percepcija osebne odličnosti ima visoko povprečno vrednost. Je rahlo asimetrična v levo in ima sploščeno obliko.

\section{Percepcija osebne odličnosti pri udeležencih izobraževanja}

Indikatorji, s katerimi smo merili percepcijo osebne odličnosti, imajo dokaj visoke povprečne vrednosti. Najnižja vrednost aritmetične 
Tabela 8: Faktorska analiza spremenljivke Percepcija osebne odličnosti udeležencev izobraževanja

\begin{tabular}{|c|c|c|c|c|c|c|c|}
\hline & & Faktor 1 & Faktor 2 & Faktor 3 & Faktor 4 & Faktor 5 & Faktor 6 \\
\hline MO & Sem neponovliiv/a in dragocen/a sebi in drugim. & 0,571 & 0,115 & 0,284 & 0,174 & 0,297 & $-0,157$ \\
\hline M1 & $\begin{array}{l}\text { Premorem veliko liubezni in si jo želim deliti, razdajati svoji } \\
\text { družini, prijateljem, liudem, ki me obdajajo. }\end{array}$ & 0,474 & $-0,049$ & 0,406 & 0,028 & 0,252 & $-0,125$ \\
\hline M2 & Zadovoljen/a sem s svojimi kariernimi cilji. & 0,51 & 0,192 & 0,301 & $-0,313$ & 0,219 & $-0,126$ \\
\hline M3 & Vsak dan si rečem: hvaležen/a sem za ... & 0,454 & 0,052 & 0,215 & $-0,277$ & 0,218 & 0,553 \\
\hline M4 & Težavnejši problem razčlenim in poiščem rešitve. & 0,487 & 0,158 & $-0,03$ & $-0,178$ & $-0,065$ & $-0,093$ \\
\hline M5 & Pomagam drugim. & 0,503 & 0,094 & 0,101 & $-0,386$ & 0,045 & 0,136 \\
\hline M6 & $\begin{array}{l}\text { Ne shraniujem neuporabnih stvari (neprebrane pošte, } \\
\text { gradiv, časopisov itd.). }\end{array}$ & 0,507 & $-0,047$ & $-0,33$ & $-0,513$ & 0,115 & 0,064 \\
\hline M7 & Če ne skrbim zase, ne morem skrbeti za druge. & 0,689 & $-0,11$ & $-0,128$ & $-0,228$ & $-0,157$ & $-0,004$ \\
\hline M8 & Spremljam uresničevanje svojih ciljev. & 0,52 & 0,26 & $-0,229$ & $-0,068$ & $-0,374$ & 0,098 \\
\hline M9 & Znam stopiti v čevlje druge osebe. & 0,556 & 0,384 & $-0,276$ & $-0,13$ & $-0,308$ & $-0,141$ \\
\hline M10 & Odgovoren/a sem za svojo kariero. & 0,682 & 0,064 & $-0,103$ & $-0,059$ & $-0,199$ & 0,157 \\
\hline M11 & Negujem osebno odličnost. & 0,585 & 0,197 & $-0,132$ & 0,198 & $-0,182$ & $-0,292$ \\
\hline M12 & Del sebe vložim v vse, kar delam. & 0,455 & $-0,54$ & $-0,1$ & $-0,084$ & 0,213 & 0,259 \\
\hline M13 & Skrbim za svoje zdravje. & 0,694 & $-0,184$ & 0,115 & 0,072 & $-0,112$ & $-0,191$ \\
\hline M14 & Vem, kaj si želim. & 0,64 & $-0,52$ & $-0,085$ & 0,093 & $-0,097$ & $-0,193$ \\
\hline M15 & Dobro uporabljam svoj čas. & 0,646 & $-0,552$ & $-0,135$ & 0,101 & $-0,029$ & $-0,167$ \\
\hline M16 & Dobro uporabljam svojo energijo. & 0,556 & 0,112 & $-0,433$ & 0,332 & 0,344 & 0,084 \\
\hline M17 & Ne gojim zamer. & 0,471 & 0,206 & $-0,446$ & 0,411 & 0,433 & 0,167 \\
\hline M18 & Ni razloga, da bi karkoli ali kogarkoli v življenju sovražil/a. & 0,38 & 0,19 & 0,2 & 0,399 & $-0,215$ & 0,37 \\
\hline M19 & Moj um je moje najpomembnejše orodje. & 0,569 & 0,069 & 0,302 & 0,254 & $-0,183$ & 0,258 \\
\hline M20 & Spodbujajo me priložnosti za spremembo. & 0,536 & $-0,156$ & 0,39 & 0,201 & $-0,283$ & 0,093 \\
\hline M21 & Sposoben/a sem hitre koncentracije. & 0,575 & 0,312 & 0,233 & $-0,026$ & 0,297 & $-0,377$ \\
\hline
\end{tabular}

sredine je pri trditvi »Težavnejši problem razčlenim in poiščem rešitve.«, najvišja pa pri trditvi »Del sebe vložim v vse, kar delam.«.

Standardni odkloni zavzemajo vrednosti od 0,582 (pri »Del sebe vložim v vse, kar delam.«) do 1,044 (pri »Težavnejši problem razčlenim in poiščem rešitve.«). Anketiranci so si najbolj enotni pri trditvi »Del sebe vložim v vse, kar delam.«, najmanj pa pri trditvi »Težavnejši problem razčlenim in poiščem rešitve.«.

Več kot polovica indikatorjev je porazdeljenih normalno, saj imajo koeficiente asime- trije in sploščenosti nižje od 1. Indikatorja »Sem neponovljiv/a in dragocen/a sebi in drugim. « in »Moj um je moje najpomembnejše orodje.« sta porazdeljena bolj sploščeno od normalne porazdelitve. Indikator »Pomagam drugim. « je porazdeljen bolj asimetrično $\mathrm{v}$ levo od normalne porazdelitve. »Če ne skrbim zase, ne morem skrbeti za druge.«, »Znam stopiti v čevlje druge osebe.«, »Del sebe vložim v vse, kar delam.« in »Ni razloga, da bi karkoli ali kogarkoli v življenju sovražil/a.« so porazdeljeni bolj asimetrično v levo in so bolj sploščene oblike od normalne porazdelitve. 
Tabela 9: Opisne statistike za posamezne indikatorje spremenljivke Percepcija osebne odličnosti

\begin{tabular}{|c|c|c|c|c|c|}
\hline Indikatorii: & $N$ & Povprečje & $\begin{array}{l}\text { Standardni } \\
\text { odklon }\end{array}$ & $\begin{array}{l}\text { Koeficient } \\
\text { asimetrije }\end{array}$ & $\begin{array}{l}\text { Koeficient } \\
\text { sploščenosti }\end{array}$ \\
\hline Sem neponovljiv/a in dragocen/a sebi in drugim. & 272 & 4,2 & 0,685 & $-0,831$ & 1,834 \\
\hline $\begin{array}{l}\text { Premorem veliko liubezni in si jo želim deliti, razdajati svoji } \\
\text { družini, prijateljem, ljudem, ki me obdajajo. }\end{array}$ & 272 & 4,26 & 0,706 & $-0,616$ & $-0,088$ \\
\hline Zadovoljen/a sem s svojimi kariernimi cilji. & 272 & 4,06 & 0,716 & $-0,39$ & $-0,079$ \\
\hline Vsak dan si rečem: hvaležen/a sem za ... & 272 & 4,08 & 0,845 & $-0,777$ & 0,515 \\
\hline Težavnejši problem razčlenim in poiščem rešitve. & 272 & 3,55 & 1,044 & $-0,559$ & $-0,011$ \\
\hline Pomagam drugim. & 272 & 4,51 & 0,643 & $-1,049$ & 0,375 \\
\hline $\begin{array}{l}\text { Ne shranjujem neuporabnih stvari (neprebrane pošte, gradiv, } \\
\text { časopisov itd.). }\end{array}$ & 272 & 3,86 & 0,945 & $-0,65$ & 0,183 \\
\hline Če ne skrbim zase, ne morem skrbeti za druge. & 272 & 4,34 & 0,737 & $-1,364$ & 3,064 \\
\hline Spremljam uresničevanje svojih ciljev. & 272 & 4,26 & 0,687 & $-0,658$ & 0,368 \\
\hline Znam stopiti v čevlje druge osebe. & 272 & 4,2 & 0,795 & $-1,081$ & 1,662 \\
\hline Odgovoren/a sem za svojo kariero. & 272 & 4,42 & 0,677 & $-0,889$ & 0,218 \\
\hline Negujem osebno odličnost. & 272 & 4,21 & 0,72 & $-0,569$ & $-0,073$ \\
\hline Del sebe vložim v vse, kar delam. & 272 & 4,53 & 0,582 & $-1,005$ & 1,243 \\
\hline Skrbim za svoje zdravje. & 272 & 3,88 & 0,793 & $-0,369$ & $-0,237$ \\
\hline Vem, kaj si želim. & 272 & 4,32 & 0,663 & $-0,768$ & 0,792 \\
\hline Dobro uporabljam svoj čas. & 272 & 3,91 & 0,81 & $-0,676$ & 0,903 \\
\hline Dobro uporabljam svojo energijo. & 272 & 3,96 & 0,777 & $-0,59$ & 0,751 \\
\hline Ne gojim zamer. & 272 & 4,14 & 0,84 & $-0,765$ & 0,168 \\
\hline Ni razloga, da bi karkoli ali kogarkoli v živlienju sovražil/a. & 272 & 4,29 & 0,82 & $-1,19$ & 1,512 \\
\hline Moj um je moje najpomembnejše orodje. & 272 & 4,4 & 0,737 & 0,276 & 4,761 \\
\hline Spodbujajo me priložnosti za spremembo. & 272 & 4,25 & 0,656 & $-0,543$ & 0,358 \\
\hline Sposoben/a sem hitre koncentracije. & 272 & 4,15 & 0,707 & $-0,544$ & 0,202 \\
\hline
\end{tabular}

\section{KLJUČNE UGOTOVITVE KVANTITATIVNE ANALIZE}

Na podlagi rezultatov obdelave vprašalnika lahko potrdim vse tri hipoteze, ki smo jih postavili na začetku raziskave.

Posamezniki, ki so izdelali osebni karierni načrt in se po njem ravnajo, spremenijo odnos do kariere in prevzamejo nadzor nad svojim življenjem, dosežejo visoko stopnjo samozaupanja in samozavesti ter imajo večjo percepcijo osebne odličnosti kot posamezniki, ki se niso karierno izobraževali in niso izdelali kariernega načrta.

Skupina A ima višje povprečne vrednosti pri vseh indikatorjih spremenljivke Odnos do kariere kot skupina $\mathrm{B}$.

S faktorsko analizo smo izmerili Odnos do kariere s pomočjo 13 indikatorjev, ki nakazujejo na dober odnos do kariere. Najnižja vrednost aritmetične sredine je pri trditvi »Pot do mojih sanjskih poklicev mi je odprta.«, najvišja pa pri »Ko razmišljam o svoji karieri, naredim nekaj zase.« 
Standardni odkloni zavzemajo vrednosti od 0,674 (pri »Zavedam se svojih kompetenc. «) do 0,969 (pri »Ko razmišljam o karieri, se mi zdi, kot da bi se mi zasvetila luč v predoru.«).

Anketiranci so si najbolj enotni pri trditvi »Zavedam se svojih kompetenc.«, najmanj pa pri trditvi »Ko razmišljam o karieri, se mi zdi, kot da bi se mi zasvetila luč v predoru.«.

Večina indikatorjev je porazdeljena normalno, saj imajo koeficiente asimetrije in sploščenosti nižje od |1l. Izjema sta indikatorja »Razmišljam o svoji karieri.« in »Čutim svojo energijo.«. Prvi je porazdeljen bolj asimetrično v levo in bolj sploščeno od normalne porazdelitve, drugi pa je porazdeljen bolj sploščeno od normalne porazdelitve.

Skupina A ima višje povprečne vrednosti kot skupina B pri vseh indikatorjih spremenljivke Samopodoba. Pri skupini A lahko z manj kot 0,1-odstotnim tveganjem trdimo, da obstaja srednje močna povezanost med odnosom do kariere in samopodobo. Spearmanov koeficient korelacije 0,465 kaže srednje močno pozitivno povezanost med spremenljivkama ( $\mathrm{K}$ in L). Boljša kot je samopodoba, boljši je odnos do kariere in obratno.

Skupina A ima višje povprečne vrednosti kot skupina B pri vseh indikatorjih spremenljivke Percepcija osebne odličnosti. Z manj kot 0,1-odstotnim tveganjem lahko trdimo, da obstaja srednje močna povezanost med odnosom do kariere in percepcijo osebne odličnosti. Spearmanov koeficient je 0,340 in kaže na srednje močno pozitivno povezanost med spremenljivkama ( $\mathrm{K}$ in $\mathrm{M})$. Boljši kot je odnos do kariere, boljša je percepcija osebne odličnosti in obratno.

$\mathrm{Z}$ manj kot 0,1-odstotnim tveganjem lahko trdimo, da obstaja zelo močna povezanost med samopodobo in percepcijo osebne odličnosti. Spearmanov koeficient je 0,652 in kaže na zelo močno pozitivno povezanost med spremenljivkama (L in M). Boljša kot je samopodoba, boljša je percepcija osebne odličnosti in obratno.

\section{VPLIV RAZISKAVE NA DRUŽBO, DRUŽBENO ODGOVORNOST IN OKOLJE}

Ugotovitve raziskave bodo praktično uporabne tudi za reševanje socialnih problemov ljudi, racionalizacijo stroškov javnih institucij, podjetij, zavodov za zaposlovanje, zlasti pa za posameznike, saj se lahko na njihovi podlagi izognejo kariernemu prelomu, ki ga prinaša brezposelnost, in ga zamenjajo s kariernim prehodom, ki ponuja različne vzorce.

Ugotovitve raziskave bodo uporabne $\mathrm{v}$ kariernem menedžmentu kot procesu načrtovanja in oblikovanja napredovanja posameznikov znotraj organizacije v skladu s potrebami organizacije ter željami, možnostmi, znanjem, spretnostmi in sposobnostmi posameznika. Karierno izobraževanje bo pripomoglo $\mathrm{k}$ uspehu organizacije, posamezniki bodo utrdili svojo samozavest in ciljno usmerjenost ter si omogočili napredovanje znotraj organizacije. Hkrati pa bodo menedžerji in organizacije prepoznali prednosti posameznikov, ki se zavedajo svojih kariernih ciljev; uskladili in poenotili želje posameznikov in potrebe organizacije; razvili nove poti za napredovanje posameznikov in pomagali posameznikom, da napredujejo, če se pokažejo znaki njihove stagnacije.

Karierni načrt kot gradnik osebne odličnosti na podlagi modela kariernega izobraževanja z vgrajenimi elementi orodij nevrolingvističnega programiranja (Turnšek Mikačić, 2010b), potrjenimi v okviru 
najnovejših raziskav nevroznanosti, je novost in še ne dovolj raziskano področje. Raziskava je izvirni prispevek in prinaša nova spoznanja, ki opozarjajo na nove paradigme razumevanja kariere in pomena njenega načrtovanja kot motiva odličnosti.

Nevrolingvistično programiranje, ki smo ga uporabili kot orodje za razvoj in dosego osebne odličnosti v okviru kariernega načrtovanja, temelji na proučevanju uspešne komunikacije in izjemnih uspehov, ki so jih dosegli ljudje na različnih področjih.

Temeljna izhodišča nevrolingvističnega programiranja prinašajo skupek tehnologij odličnosti ter uspeha $\mathrm{v}$ učenju in življenju. Revolucionarno odkritje, da se možgani lahko spreminjajo in vzpostavijo nove strukture, hkrati tudi pomeni, da lahko možgani zgradijo nove povezave, ustvarijo nove vizije, nadomestijo slabe občutke ali popravijo učinke bolezni.

Predstavljena raziskava je izvirni prispevek na področju raziskovanja nove paradigme razumevanja kariere in pomena njenega načrtovanja kot motiva odličnosti. Kaže na to, da karierno načrtovanje omogoča posamezni$\mathrm{ku}$, da se nenehno prilagaja in pridobiva nove kompetence.

Če bi naša družba v širšem smislu spodbujala izdelavo kariernih načrtov v podjetjih, bi se izognila mnogim neskladjem med brezposelnimi in nadomestilom, ki jim ga ponuja $\mathrm{v}$ določenih obdobjih. Namesto da bi se ljudje ob brezposelnosti spopadali s prelomom svoje kariere in bili nenehno v stresnem stanju, bi s pomočjo kariernega načrta laže prehajali iz ene kariere v drugo. Država je dolgo časa vlagala velika sredstva za saniranje tekstilnih in usnjarskih podjetij, podjetij s področja predelave papirja, zdaj so pred tem gradbena in trgovska podjetja, tisoči delavcev pa ostajajo na cesti. Ves kapital, namenjen za pomoč lastnikom, bi bil lahko koristno porabljen tako, da bi zaposleni v času pred kriznim obdobjem pridobivali nove poklice, nove veščine, znali voditi nove projekte ter bili sposobni in finančno opremljeni za zagon novih dejavnosti, novih skupnih projektov trženja.

Osebni karierni načrt bi ljudem zarisal karierno delo daleč v prihodnost. Model kariernega izobraževanja in rezultati raziskave odpirajo smeri raziskovanja o vplivu kariernega načrtovanja na navedene družbenoekonomske učinke.

\section{LITERATURA IN VIRI}

Likert, R. (1932). »A Technique for the Measurement of Attitudes «. Archives of Psychology, 140: $1-55$.

Statistični urad Republike Slovenije. Podatkovni portal SI-Stat (dostopno 20. 8. 2012).

Turnšek Mikačić, M. (2010a). »Osebni karierni načrt kot orodje kariere 21. stoletja«. V: Učinkovit razvoj kariere zaposlenih kot priložnost za rast podjetij (elektronski vir): zbornik prispevkov 1. konference o kariernem coachingu. Ljubljana: Glotta Nova.

Konferenca o učinkovitem razvoju kariere zaposlenih in priložnosti za rast podjetij (2007). Ljubljana: Državni svet Republike Slovenije.

Turnšek Mikačić, M. (2010b). »Etičnost razmišljanja in delovanja pri uveljavljanju osebne odličnosti«. V: Bukovec (ur.), Etičnost razmišljanja in delovanja pri uveljavljanju strategije univerzalne odličnosti in mojstrstva. Novo mesto.

Turnšek Mikačić, M. (2013). Karierni načrt kot gradnik osebne odličnosti. Osnutek doktorske disertacije. Novo mesto: Fakulteta za organizacijske študije. 